International Journal of Modern Research in Engineering \& Management (IJMREM)

||Volume|| 2 ||Issue|| 11 ||Pages|| 74-87 || November 2019 || ISSN: 2581-4540

\title{
The Attitude of Graduate students toward Research and their Intention to Conduct Research in the Future
}

\author{
${ }^{1,}$ Damianus Abun, ${ }^{2}$ Theogenia Magallanes, ${ }^{3,}$ Sylvia Lalaine Foronda, ${ }^{4}$ Mary Joy \\ Incarnacion \\ 1, Ph.D.: Divine Word College of Vigan \& St. Benedict College of Northern Luzon, Philippines \\ ${ }^{2}$ Ed.D: St. Benedict College of Northern Luzon, Philippines \\ ${ }^{3}$ Ph.D: Divine Word College of Laoag, Philippines \\ ,4, Ph. D (Candidate): Divine Word College of Vigan, Philippines
}

\begin{abstract}
The purpose of the study was to determine the relationship between cognitive and affective attitude of students toward research and their intention to conduct research. To support the objective of the study, theories along human attitude and human behaviour, the concept of academic research were reviewed and studies in line with the current study was also reviewed. The study uses descriptive correlational and quantitative study. The population of the study was all Master in Business Administration students of Divine Word Colleges in Ilocos Region. The data were gathered through validated questionnaires. To interpret the data, the statistical tools were used such as weighted mean was applied to determine the level of cognitive and affective attitude of students and their behavioural intention to conduct research. While Pearson $r$ was used to determine the relationship between cognitive and affective attitude and behavioural intention to conduct research. The study found that there is a correlation between cognitive and affective attitude, both positive and negative attitude, toward research and the intention to conduct research. Thus, the hypothesis of the study is accepted.
\end{abstract}

KEYWORDS: cognitive attitude, affective attitude, behavioural intention, research, human attitude and behavior

Date of Submission: Date, 12. October 2019

Date of Publication:15. November 2019

\section{INTRODUCTION}

Research subject has been included as one of the core subjects of the Graduate School Students. All students have to take the subject and should produce a research output as a requirement for the degree. I believe that the reason why such subject is included in the Graduate studies because of the fact that research is the source of any development in society. The quality of life cannot be separated from research. Innovative product or services are the product of research. It is the very reason of why every industry or business must have research unit. It is based on the belief that there is nothing new or new development as coming out of the blue without research. It has been recognized that product innovation or teaching innovation is depending on research. Because of innovation in many aspects of life, human beings cannot enjoy the present state of life with its newest technology without research. Life becomes so easy and comfortable because of research. Knowing its importance to human development and human welfare, research becomes indispensable subject in the school, not only in the graduate school but it starts from Senior High School. In fact, school should be research-based because it is where the innovations are discovered and it is where research is learned. Therefore, schools are considered as training ground for all future practitioners and innovators. In this case, the responsibility of schools is to equip everyone the knowledge and skills on how to conduct research. In order to achieve this purpose, the duty of teachers is to disseminate theory of research and to teach how to do it. In this case, they should know how to conduct research and only then, they can inspire students, the future innovators to conduct research. But sad to say that many are still afraid of research, finding it hard or difficult (Monir, and Bolderston (2009), Oguan, Bernal and Pinca (2014). Studies have shown that teachers and students altogether find it difficult to conduct research. Though some have positive attitude toward research but many of them have negative attitude toward research. Within this reality, the current study would like to go deeper behind the positive and negative attitude toward research of students and find out if this attitude affects their plan to conduct research. 
The Objective of the Study: The study intends to find out if the students are interested or not interested in research and to find out if they will write their research. The result of the study will be used as sources of information to the decision makers in relation to the research to the Graduate school and determine ways how to make research interesting. The output of the study can be a contribution to the management of the school to review the research policies particularly to the graduate students.

\section{THEORETICAL FRAMEWORK}

Understanding Human Attitude: Attitude is an individual's disposition to react to certain object, behaviour, person, institution, event or other discriminable aspect of the individual's world (Ajzen, 1993). Ajzen contended that there can be a lot of definitions of attitude from different theorists, however, there is a common agreement among them that attitude has its evaluative dimension (Bem, 1970, Edwards, 1957, Fishbein \& Ajzen, 1975). In the sense that dimensions of attitude can be measured and evaluated. Ajzen (1993) recognized that though attitude is inaccessible to observations because it is within the person's mind or it is latent but it can be measured through the reaction or responses of the person toward the object of the attitude which may be favourable or unfavourable toward the object, persons, institution, events or situations. There are three categories of responses or reactions and they are cognitive, affective and conative responses (Allport, 1954, Hilgard, 1980, Rosenberg \& Hovland, 1960). These are manifestations of salient or latent attitude which is unobservable (Ajzen, 1993). Cognitive component refers to the beliefs and thoughts about the subject, the object, the person, the institution, the event, etc. It is about the perception and information of the person toward the subject, object or the person. Affective component of attitude is an emotional reaction toward the subject, object or the person. It is how one feels when he/she is confronting the subject, object, the person or the institution. It is still a psychological reaction which may be verbal or nonverbal expression of feelings toward the subject, object, the person or the institution. Such reaction may be negative or positive. While conative component of attitude is the effect of the attitudes toward a behavioural intention or how the attitude affects one's behaviour. These may include plans, intentions and commitments to a planned behaviour. These are the three components of attitude and therefore, attitude is a multidimensional construct.

The question can be raised in relation to the origin of attitude: where does it come from? According to Ajzen (1993), a person develops such attitude perhaps as a result of watching television program or may be other kind of exposures or experiences. But Abun (2017) went deeper to answer that question in relation his argument on how to solve environmental problem. According to him, that environmental problem is a result of human behaviour and destructive human behaviour is originated from the culture and thus solving environmental problem is to revisit the culture that have influenced the mind of people toward the environment. He contends that attitude is originated from the culture where the person is raised. His argument was based on the ideas of anthropologists such as Donald (2002), Hofstede as cited by Brown (1995). Donald (2002) argued that culture is playing important role on our brain functioning and even brain structure. She has pointed out that language has the biggest impact on brain structure but that culture influences brain functioning to a great extent as she writes:

The social environment includes many factors that impinge on development, from bonding and competitive stress to the social facilitation of learning. These can affect brain functioning in many ways, but usually they have no direct influence on functional brain architecture. However, symbolizing cultures own a direct path into our brains and affect the way major parts of the executive brain become wired up during development. This is the key idea behind the notion of deep enculturation... This process entails setting up the very complex hierarchies of cognitive demons (automatic programs) that ultimately establish the possibility of new forms of thought. Culture effectively wires up functional subsystems in the brain that would not otherwise exist.

The idea of culture and its effect on brain functioning indicates the power of culture over the formation of the mind and ideas of people about everything around them (Abun, 2018). Donald's View is similar to what Hofstede as cited by Brown (1995) as he argued that culture is the collective programming of the human mind that distinguishes the members of one human group from those of another. Hofstede pointed out clearly that that culture is reflected in how people think, how people view things or attitude. To elaborate the idea of Hofstede, Amstrong (1996) contend that there is a relationship between cultural dimensions and ethical perceptions.

In other words, ethical attitude is formed by a particular culture. One perceives certain object, subject, person or institution to be negative or positive, favourable or not favourable because he/she has been taught by the culture of a particular society where he/she is living. What he/she learns from the culture will be his/her ideas about certain subject, object or events, etc. that he/she will encounter. 
Understanding Human Behaviour: To understand the root cause of human behaviour, it would be helpful to revisit the idea of William James, a pragmatist, a behavioural psychologist, as cited by Lawler (2006). James is against the idea that all human behaviour is shaped by experience but it is shaped by the brain or the mind. Though James recognized that humans are ruled by their instincts as other animals do, but what make humans behave the way they do and how they behave the way do is different from animals. James went on to explain that though humans are animals with the most instincts but they will never react automatically to the instincts, the way inferior animals do because humans have the mind or the reason. It is the role of reason. Reason has to create another impulse to neutralize another impulse. To complicate further the root cause of human behaviour, Ridley (2011) turns his attention to the nature versus nurture debate to bring the first popular account of the root of human behaviour with this unique question: "what makes us who we are?" This question is related to the main question of why humans behave the way they do and how they behave the way they do.

The immediate answer to these questions may point to the very essence of human being that differentiates it from animal which is the reason or the mind. But Nohria, and Lawrence (2003), instead of pointing at reason or mind as the source of human behaviour, she pointed out four drives or qualities that shape human behaviour. According to her, these drives or qualities are important to understand why humans behave the way they do. These qualities or drives are conflicting and they do not work automatically. They force us to make deliberate decisions and choices with certain degree of liberty. According to this argument, drives or qualities that shape our human behaviour are first, drives to gain object, bodily and emotional experience, maintaining life and improving one's social status in relation to others. Second, drive to create relations, to belong to a group and create a long terms relationship and caring for others. Third, drive to gain insight including understanding one's self and one's surroundings. Fourth, drives to control and defend. These are the qualities for us to understand why we behave in a certain way.

In other words, human behaviour is driven by purposes to be accomplished, not just like other animals. The later argument brings us to the theory of planned behaviour of Ajzen (1985, 1987, Ajzen \& Madden, 1986). Theory of planned behaviour (TPB) is an extension of theory of reasoned action to explain the relationship between attitudes and behaviour within the human action. Reasoned Action Theory (RAT) argues that reason for action will predict how individual will behave based on their pre-existing attitude and behaviour intention. The theory argues that an individual will behave based on the expected outcome the individual expects to achieve as a result of performing such behaviour (Fishbein \& Ajzen, 1975, Ajzen \& Fishbein, 1980). If RAT focuses on the reason, while the central attention of Theory of Planned Behaviour or TPB is the individual's intention to perform a given behaviour. There are three independent determinants of intention. First determinant is the attitude toward the behaviour. At the level, the person who perform certain behaviour must evaluate if the behaviour in question is favourable or not favourable. Second determinant is social factor or subjective norms. At this level, the person who perform the act must evaluate if the society is in favour or not in favour of such act or behaviour. Third is the novel antecedence of intention. This refers to the perceived ease or difficulty of performing the behaviour and it is assumed to reflect past experience on performing the behaviour and anticipated impediments and obstacles in performing the behaviour. It suggests that the more favourable the attitude and subjective norms with respect to a behaviour, and the greater the perceived behavioural control, the stronger should be an individual's intention to perform the behaviour under consideration (Ajzen, 1993). In short, the theory of planned behaviour argues that the stronger people's intention to perform certain behaviour, or the stronger people's intention to achieve their behavioural goals the more likely they engage in such behaviour. However, Ajzen (1993) cautions us that the degree of success does not depend only on intention but there are circumstances that may prevent us to realize the behaviour in consideration and these may include opportunities and resources such as time, money skills, and other necessary requirements to perform such behaviour. These factors represent the actual control over the behaviour. Beyond that, since TPB is concerned with the perceived behaviour, the particular perceived behaviour may not be carried out due to lack of information about the behaviour, the requirements have changed and when other unpredicted elements have entered into the situation.

The influence of Attitude toward Behaviour : In psychology, an attitude is defined as a set of emotions, beliefs, and behaviours toward a particular object, person, thing, or event (Banaji \& Heiphetz, 2010). It is a learned tendency to evaluate or perceived things in a certain way and therefore one can have positive or negative evaluation or perception of certain objects, experiences, practices, etc. The evaluation or perception of a person toward certain object or experience is not isolated from experiential exposure. It has been a common understanding and agreement that attitudes are results of experience, upbringing/education and social interactions. Experience or upbringing or education can have powerful influence over attitudes. However, since attitude is not independent from environment or experience, thus it is also accepted that attitudes are dynamics in the sense that it is enduring and the same time it can also be changed (Cherry, 2019). 
Most of the early researches on attitude accepted as a given that attitude influenced the behaviour. The background of those studies was influenced by the ideas of the early social psychologists that attitude is a key to understand human behaviour (Thomas \& Znaniecki, 1918, Watson, 1925). This idea was taken for granted for quite some time until the time that later studies proved otherwise. Some investigators challenged the earlier assumption through field studies on the relationship between attitude and behaviour and their studies found that there was no correlation or little correlation between attitude and behaviour. For example, Corey (9137), Freeman \& Ataoev, (1960) as cited by Ajzen (1993) conducted a study on the college's students' attitude at the beginning of the semester and provide multiple opportunities to cheat by allowing them to score their own test. His test found that there was no correlation between students' attitude and their cheating behavior (Ajzen, 1993, p.74). Even later studies supported the study of Corey (1937).

For example, Dean (1958) conducted a study on attitude toward labour unions and participating in labour union meetings, and his study found no correlation. The similar study was also done by Wicker and Pomazal, (1971) on the attitude toward participating a subject in social psychology and actual participation in social psychology class. Their studies found no correlation. The finding of later studies particularly the study of Wicker (1969) seem discouraging the original idea of early social psychologists that attitudes is the key to predict behaviour. The results of those studies have questioned the importance of studying the personal disposition and behaviour. By 1970s most social psychologists accepted the negative verdict of the relation between attitude and behaviour. Instead of studying the relation between attitude and behaviour, they encouraged the study of social context and norms as determinant factor in predicting the behaviour or human action (De Fleur \& Westie, 1958, Deutscher, 1969).

However, given those negative result, other social psychologists, particularly Ajzen and Fishebin (1977, 2000,) still maintain that attitude is still key to predict the behaviour (Allport, 1968). Allport (1968) still considered attitude to be "the most distinctive and indispensable concept in contemporary American social Psychology" (p. 59). Other social psychologists who were against the negative finding of early research argued that the inconsistencies are not with the attitude and behaviour itself but it may happen because of many factors such as response biases, multidimensionality of attitudes, and moderating variables. In terms of response biases, they argue that there is a tendency to give socially desirable responses on attitude and personality inventories and along this point, they recommended the need to use attitude measures that are less subject to systematic biases (Ajzen, 1993). In relation to multidimensionality of attitudes, they pointed out that most attitude measurement technique resulted in a single score representing the respondent's overall positive or negative reaction to the attitude object. According to them, focus on a single dimension did not do justice to the complexity of the attitude construct (Allport, 1935). Single construct is against attitude as multidimensional construct which include cognition, affective and conation component (Rosenberg \& Hovland, 1960). Lastly, the inconsistencies are due to moderating variables.

They argued that the degree of attitude behaviour consistency was assumed to be moderated by factors related to the person performing the behavior such as self-awareness, self-efficacy, self-monitoring, experience, selfconfidence, even feeling and lack of information or knowledge. They also pointed out to the situation as moderating variable such as time pressure or circumstances surrounding performance of the behaviour (Ajzen, 1993). The recent studies conducted by Abun (2018) and Fitzsimmons and Douglas (2005) confirmed the consistency of attitude and behavior. Abun (2018) measured the relationship between environmental attitude and environmental behavior and the study found that environmental attitude predicted the environmental behaviour of the students and employees toward the environment. Further, he also conducted a study on the entrepreneurial attitude and future intention to establish a business and the finding also indicated a correlation. The study of Fitzsimmons and Douglas (2005) also found that entrepreneurial attitudes are significant in explaining career decision in the future and their intention to go into business.

Research in Education: Life could not move far as we have been enjoying at the present without research. Life becomes better and pleasurable because of research. We could not enjoy riding on the airplane, car, motorcycle, ship, cell phone without research. Life becomes easier, work becomes easier and faster, travel becomes shorter, products keep on changing because of research. Along this development, we cannot deny fact that what makes the difference between one countries from another, one school from another, one business from another, one teacher from another is research. America is faster in terms of technological development compared to other countries is because of research. Research and development are two inseparable topics because one cannot talk about development without research. Along this line, in 1965, David Novic as cited by Godin (2003) and Lane (2010) suggested, "We should stop talking about research and development as though they were an entity and examine research on its own and development as a separate and distinct activity". 
In short, the primary role of research is to enable man to have a better life (Ariola, 2006). Research becomes so important in human development and it plays important role in our daily life. We may cite what Zarah (2019) had said about the importance of research which may include building knowledge and facilitating learning. It is process of collecting and analysing information about problem on hand in order to gain understanding of the problem under study (Swindoll, 2012). This concept alone gives us broader importance of research that through research we have gained knowledge, new understanding about many issues of life and help us to make decisions or solve problems effectively. Practically all aspects of problems of life and its development can be solved by research. Research makes life easier and better.

Thus, research is everyone's business. But in academic context, research is not so simple. Research becomes academic term that attach to the meaning of education. Research is to carefully analyse the problems or to do the detailed study of the specific issues or problems by making use of scientific method (Reddy, 2019). By this definition, we can say that research is not an innate knowledge that everyone knows by nature as a human being. Research must be learned how to do it through education. One must know the theory or method of research and know how to apply those method into actual research. Solving problems and finding new solutions have to follow the process of research which may be started by the statements of the problems, hypothesis and methodology on how to investigate the problems before finding solution to the problem (Ariola, 2006). As we have emphasized earlier that research is not innate knowledge but it is learned. This concept brings us to the role of education. Education is to teach people how to do research. This is the first thing to be introduced to students when they enter university or college. The purpose is to familiarize students on how to conduct an academic research, to connect students to research, to encourage students and educators to reflect upon the research process to enable them to position themselves into the bigger picture of learning, and encourage pedagogic culture (Groessler, 2017). In short, teaching research is actually to orient the mind of students and even teachers themselves that education is actually research. Research is the culture of education, in the sense that it is the business of everyone, not only teachers but also students. Educational process must be the output of research and student-teacher interaction in the classroom must lead them into further investigation or research.

The argument above leads us to argue that teaching and learning involve research. The two, teaching and learning are inseparable topics for a teacher and thus research is a must for teachers and students. Teaching, learning and research are the main concern of education, main concern of teachers and students. By saying this means that the job of a teacher is teaching and at the same time doing research and the job of students is learning through research. As a teacher, her/his job is to teach but in order to teach well, he/she must conduct research. In other words, teaching must be based on research. To advance in teaching and learning, a teacher requires considerable time to conduct research, then publication and presentation. Research does not end with research activity itself but it has to be published in the appropriate journal and finally to be presented. Both teaching and research can help a teacher to develop insights into his/her field, refine his/her knowledge and communication skills and draw on his/her ability to select and organize content in a meaningful way. While for the students, learning is not only by reading and listening to teachers but developing knowledge through their own investigation or research.

\section{RELATED STUDIES ON ATTITUDE TOWARD RESEARCH}

It has been said that one of the well-established hallmarks of a profession is its ability to generate research to expand its unique professional knowledge base. It is expected that all people who are in the business, education or health practitioners must be familiar with research and must conduct research. Service innovations can only happen if there are researches on the different areas of the services. But sad to say that not all people who are in the profession engage in research. The reason is simple, that not all people have a good or positive attitude toward research and do not have enough knowledge and skills toward research. Studies on measuring attitude toward research have been done by many researchers but those studies were only to measure the attitude toward research and only few researchers were done to measure the effect of such attitude toward conducting actual research or the intention or the plan to conduct research in the future. Many studies have been done to measure the attitude of students across disciplines toward research. For example, Shaukat, Siddiquah, Abiodullah and Akbar (2014) tried to measure the attitude of post graduate students toward research in Pakistan. The study dwelt on the hypothesis that students hold positive ideas toward different aspect of research. In line with such hypothesis, five constructs were investigated particularly on the usefulness of research for a career, research anxiety, positive attitude toward research, research's relevance to life, and research difficulty.

The results were compared between male and female. The study found that male had significantly positive attitudes towards research than the females along those five constructs. The finding was also confirmed by the finding of Oguan, Bernal, and Pinca (2014) that the male students are more positive compared to their female counterparts. 
However, similar study of Bibi, Iqbal and Majid (2012) argued otherwise that male and female students have almost the same level of attitude toward research. Within the same interest, Belgrave, and Jules (2015) conducted a study on the attitude of students toward research. The study also found that students had a positive attitude toward research and it validated the hypothesis that students' perceptions of the functionality of research and its meaningful application to real-life situations results in a positive attitude towards research. Positive attitude can be a result of knowledge on research as pointed out by Hofmeister (2007), Kakupa and Zue (2019) and Seher (2018). By comparing Master students' and Doctoral students' attitude toward research, their study found that Doctoral students have more positive attitude toward research compared to Master students. Students who had more exposure to scientific research had positive attitude toward research (Seher, 2018). Therefore, the study pointed out that self-efficacy is positively related to positive attitude toward research as pointed by Oguan, Bernal, and Pinca (2014) that those with a high academic qualification and academic grade display a high positive attitude towards research (Rezaei, 2013).

Therefore Memarpour, Fard and Gashemi (2015), Monir, Bolderston (2009) suggested to provide greater availability of information in order to solve the problems related to self-efficacy and engage in research. Beside positive attitude toward research, there have been a lot of studies also pointing out the negative attitude toward research. Monir, and Bolderston (2009) had pointed in their study about the attitude and the perception of students toward research. The study revealed that students have negative attitude toward research and because of such negative attitude, the students have general disinterest in conducting research. They argued that general disinterest in research is the most common reason why students are not engaging in research. This was also confirmed by Oguan, Bernal and Pinca (2014) that most students have negative attitude toward research and they found research to be difficult. Though students recognize its usefulness and importance but they find it difficult and anxious toward research (Al Furaikh, et.al, 2017) and this attitude was caused by their lack of knowledge about research as pointed out by Kleinbaum and Swenson (1984), Kumari, et.al (2018). Feeling that research is difficult is discouraging students to conduct research as it is found that this is one of the reasons why graduate students do not finish their studies ( Kleinbaum and Swenson, 1984). In terms of attitude and the intention to conduct research in the future, the previous studies have a mixed answer. Though students have positive attitude toward research and see research as useful in their profession and for their promotion, however, studies showed that positive attitude will not always translate into action, will not translate into plan to conduct research in the future. They cited many reasons along this line. For example, Siamian (2015) in his study found that students had a very positive attitude toward research, and it is useful in their life but such positive attitude did not correlate to their plan to conduct research in the future.

They somehow pointed out the reasons why they are discouraged to go into research such availability of resources and research facilities. Beside the availability of research facilities, students also pointed out lack of knowledge in conducting scientific research and supportive environment (Soe, et.al, 2018), lack of guidance, funding and professional trainings (AlGhamd, et.al, 2014), Al Furaikh (2017), lack of experience in scientific activities (Seher, 2018), lack of time because educational tasks (Abulata, et.al, 2019), lack of documentation and maintenance of records, (Basudan, et.al, 2019). However, those findings may not be conclusive because some studies also found that positive attitude and self-efficacy correlates to the conduct of research. For example, Rezaei and Miandashti (2013) conduct a study on the attitude and self-efficacy of Master of Science student and Doctoral students toward research, the study found that students who have high self-efficacy and positive attitude toward research correlated to the number of published research paper. Likewise Basudan, et.al (2019) conducted a study on the accountants' and specialists' attitude toward research and the study found that majority of them have positive attitude toward research and are willing to conduct research and are willing to apply research outcome in their practice and they also believed that by conducting research helps their profession and increases their knowledge. It was also found that students who have training in research have positive attitude toward research and possibility to conduct research (Kumari, et.al, 2018). 


\section{Conceptual Framework}

Independent Variables

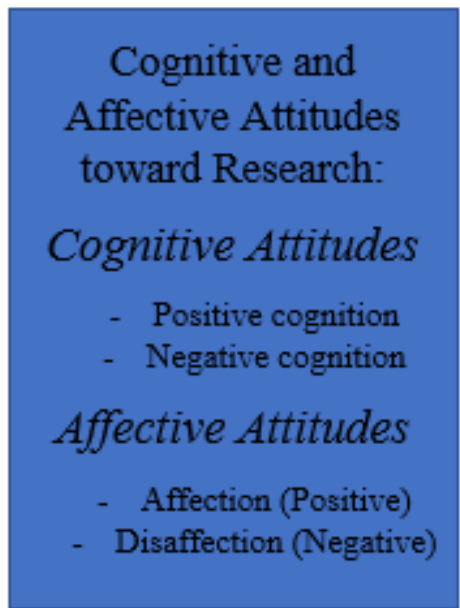

Dependent Variable

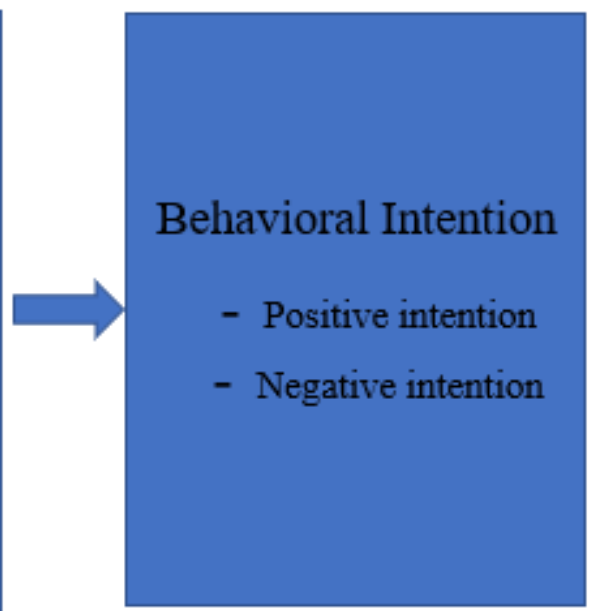

Figure 1: The conceptual framework reflects the independent and dependent variables. It depicts one variable affects the other variable. Attitudes affect the behavioural intention.

Statement of the problems: The study wants to determine the relationship of attitudes of students toward research and how it affects the behavioural intention of students to conduct research. Specifically, it seeks to answer the following questions:

1. What is the cognitive attitude of students toward research in terms of

a. Positive cognition

b. Negative cognition

2. What is the affective attitude of students toward research in terms of

a. Affection

b. Disaffection

3. What is the behavioural intention of students to conduct research in terms of

a. Positive intention

b. Negative intention

4. Is there a relationship between cognitive and affective attitudes toward research subject and behavioural intention of students to conduct research?

Assumption : The study assumes that attitudes toward research affects the behavioural intention to conduct research and it can be measured. Attitude has predictive validity and it helps us explain human social behaviour.

Hypothesis: Ajzen (1985, 1987), Ajzen \& Madden, (1986) have argued that attitudes affect the human behaviour and base on this theory, the current study argues that attitudes of students toward research affect their behavioural intention to conduct research in the future.

\section{METHODOLOGY}

The study was carried out through appropriate research methodology such as research design, data gathering instruments, population, locale of the study, data gathering procedures and statistical treatment of data.

Research Design: Since the study is a quantitative research and therefore it used descriptive correlational research design and aided by inquiry to determine the level of attitudes of students toward research and behavioural intentions to conduct research. The nature of descriptive research is to describe what is found in the data collected through questionnaires and statistical treatment. It is also used to describe profiles, frequency distribution, describe characteristics of people, situation, phenomena or relationship variables. In short, it describes "what is" about the data (Ariola, 2006, cited by Abun, 2019). In line with the current study, descriptive correlational method was deployed. The study determines the level of attitude toward research and its correlation 
with the plan to conduct research. This was to determine what the dominant attitude of students toward research were and what particular attitudes affects the behavioural intention to conduct research.

Locale of the Study : The locale of the study was Divine Word Colleges in Ilocos Region which are composed of Divine Word College of Vigan. Divine Word College of Vigan belonged to the Province of Ilocos Sur and located within the heritage city of Vigan. Divine Word College of Laoag is located in Laoag City, Ilocos Norte. Divine Word Colleges in Region I are run by the Congregation of the Divine Word Missionaries or known as Society of the Divine Word or in Latin, Societas Verbi Divini (SVD).

Population : The population of the study was composed of all MBA graduate students of Divine Word Colleges in Ilocos region. Since the total numbers of MBA graduate students are limited, and therefore total enumeration is the sampling design of the study.

Data Gathering instruments : The study utilized validated questionnaires. The questionnaires were adapted from ATR scale or Attitude toward Research Scale of Papanastasiou (2014).

Data Gathering Procedures : In the process of data gathering, the researcher sent letters to the President of the Colleges, requesting them to allow the researcher to flow his questionnaires in the college. The researcher personally met the Presidents and students and requested them to answer the questionnaires. The retrieval of questionnaires was arranged between the President's representative and the researcher with the help of employees and faculty of the college.

Statistical Treatment of Data : In consistent with the study as descriptive research, therefore descriptive statistics was used. The weighted mean is used to determine the level of attitude toward research and behavioural intention to conduct research and the Pearson $r$ was used to measure the correlation of attitudes toward research and the behavioural intention to conduct research.

The following ranges of values with their descriptive interpretation will be used:

Statistical
$4.21-5.00$
$3.41-4.20$
$2.61-3.40$
$1.81-2.60$
$1.00-1.80$

Descriptive Interpretation

strongly agree
Agree
somewhat agree
Disagree
Strongly disagree

\section{Overall Descriptive Rating \\ Very High \\ High \\ Moderate \\ Low/High \\ Very Low/Very High}

\section{FINDINGS}

The presentation of the findings of the study is following the arrangement of the statement of the study. The study wants to determine the relationship between cognitive and affective attitude of students toward research and their behavioural intention to conduct research. It seeks to answer specifically the following questions:

\section{What is the cognitive attitude of students toward research in terms of \\ a. Positive cognition \\ b. Negative cognition}


The Attitude of Graduate students toward Research...

Table 1. Student's cognitive Attitude toward Research as to positive and Negative Component

\begin{tabular}{|c|c|c|c|}
\hline \multicolumn{1}{|c|}{ Indicators } & Mean & DR \\
\hline a. & Positive Component & 4.53 & SA \\
\hline 1 & Research is useful for my career & 4.65 & SA \\
\hline 2 & Research is important for enriching my knowledge & 4.21 & $\mathrm{~A}$ \\
\hline 3 & Research should be indispensable in my professional training & 4.13 & $\mathrm{~A}$ \\
\hline 4 & Research should be taught to all students & 4.47 & $\mathrm{~A}$ \\
\hline 5 & Research is useful for every professional & 4.40 & $\mathrm{~A}$ \\
\hline 6 & Research is very valuable for human life & 4.40 & $\mathrm{~A}$ \\
\hline & Composite Mean & 3.56 & $\mathrm{~A}$ \\
\hline b. & Negative Component & 2.76 & SWA \\
\hline 1 & Research is difficult because it follows certain method of investigation & 1.89 & $\mathrm{D}$ \\
\hline 2 & The concept of research is hard to understand & 2.21 & $\mathrm{D}$ \\
\hline 3 & Research is irrelevant to my career & 1.93 & $\mathrm{D}$ \\
\hline 4 & Research complicates my work & 2.47 & $\mathrm{D}$ \\
\hline 5 & Research should not be part of teaching requirement & & \\
\hline & Composite Mean & & \\
\hline
\end{tabular}

\section{Legend}

4.21-5.00

$3.41-4.20$

$2.61-3.40$

$1.81-2.60$

$1.00-1.80$

strongly agree
Agree
somewhat agree
Disagree
Strongly disagree

Very High
High
Moderate
Low/High
Very Low/Very High

Based on the data gathered, it reveals that as a whole, students' cognitive attitude toward research in terms of its positive component is 4.40 which is interpreted as "agree" or "high". This is supported by its individual items. Taking it singly, it shows that students agree that research should be indispensable in the professional training (4.21), should be taught to all students (4.13), is useful for every professional 94.47), and very valuable for human life (4.40). Students even strongly agree that research is useful for their career (4.53) and it is important for enriching knowledge (4.65).

The result of its negative component is supporting the positive component. The data reveals that as a whole, students' cognitive attitude toward research in terms of its negative component is 2.47 which means disagree. Taking it singly, the data indicates that students disagree that research is irrelevant to their career (1.89), research complicates their work (2.21), and they disagree that research should not be part of teaching requirement (1.93) but they agree that research is difficult because it follows certain method of investigation (3.56) and somewhat agree that the concept of research is hard to understand (2.76).

\section{What is the affective attitude of students toward research in terms of a. Affection \\ b. Disaffection}

Table 2. Student's affective Attitude toward Research as to positive and negative Component

\begin{tabular}{|c|c|c|c|}
\hline \multicolumn{2}{|r|}{ Indicators } & Mean & DR \\
\hline \multicolumn{4}{|c|}{ a. Positive Component } \\
\hline 1 & Research is interesting & 3.92 & A \\
\hline 2 & Research is enjoyable & 3.60 & $\mathrm{~A}$ \\
\hline 3 & Research excites me & 3.54 & A \\
\hline 4 & Research makes me great & 3.82 & A \\
\hline 5 & Research gives me a great feeling & 3.70 & A \\
\hline \multicolumn{2}{|r|}{ Composite Mean } & 3.72 & $\mathbf{A}$ \\
\hline \multicolumn{4}{|c|}{ b. Negative Component } \\
\hline 1 & Research makes me nervous & 3.12 & SWA \\
\hline 2 & Just thinking of research is stressful & 3.12 & SWA \\
\hline 3 & Thinking of research makes me anxious & 3.10 & SWA \\
\hline
\end{tabular}


The Attitude of Graduate students toward Research...

\begin{tabular}{|c|l|c|c|}
4 & Research scares me & 2.80 & SWA \\
\hline 5 & Research makes me upset & 2.50 & D \\
\hline 6 & Research gives me headache & 2.70 & SWA \\
\hline & Composite Mean & $\mathbf{3 . 0 7}$ & SWA \\
\hline
\end{tabular}

\section{Legend}

$4.21-5.00$
$3.41-4.20$
$2.61-3.40$
$1.81-2.60$
$1.00-1.80$

strongly agree
Agree
somewhat agree
Disagree
Strongly disagree

\author{
Very High \\ High \\ Moderate \\ Low/High \\ Very Low/Very High
}

Based on the data gathered, it shows that as a whole, students' affective attitude toward research in terms of positive affection is 3.72 which means agree. Students agree that research is interesting (3.92), enjoyable (3.60), excites me (3.54), makes me great (3.82) and gives me a great feeling (3.70).

However, on the negative side of it, as a whole, students' affective attitude in terms of their disaffection toward research is 3.07 which means they somewhat agree? They do not deny the fact that research makes them nervous (3.12), stressful (3.12), anxious (3.10), scares them (2.80) and gives them headache (2.70) but they disagree that research makes them upset (2.50).

\section{What is the behavioral intention of students to conduct research in terms of a. Positive intention \\ b. Negative intention}

Table 3. Student's Behavioural Intention to conduct Research

\begin{tabular}{|c|c|c|c|}
\hline \multicolumn{2}{|c|}{ Indicators } & Mean & DR. \\
\hline \multicolumn{4}{|c|}{ a. Positive Behavioural Component } \\
\hline 1 & I will employ research approach in my profession. & 3.99 & A \\
\hline 2 & I have the skills to write and I will conduct research. & 3.70 & A \\
\hline 3 & I will theories of research in writing my thesis & 3.90 & A \\
\hline 4 & I am inclined to study the details of my research and will apply it in the future. & 3.91 & A \\
\hline 5 & I will really conduct research. & 3.85 & A \\
\hline \multicolumn{2}{|r|}{ Composite Mean } & 3.87 & $\mathbf{A}$ \\
\hline \multicolumn{4}{|c|}{ b. Negative Component } \\
\hline 1 & Research is difficult and I cannot make it. & & \\
\hline 2 & I have no skills in research and I have no plan to do it. & 2.21 & $\mathrm{D}$ \\
\hline 3 & I find it hard to understand the concept of research and I can't apply it. & 2.06 & $\mathrm{D}$ \\
\hline 4 & I have no enough knowledge in research and I will never do it. & 2.17 & $\mathrm{D}$ \\
\hline 5 & Even if I am promised of promotion for conducting research, I will not do it. & 2.12 & $\mathrm{D}$ \\
\hline \multicolumn{2}{|r|}{ Composite Mean } & 2.11 & D \\
\hline
\end{tabular}

Legend

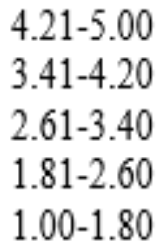

strongly agree
Agree
somewhat agree
Disagree
Strongly disagree

\section{Very High \\ High \\ Moderate \\ Low/High \\ Very Low/Very High}

Looking into behavioural components, data reveals that as a whole, students' behavioural intention to conduct research is 3.87 which is interpreted as agree. Even when the items are taken singly, it reveals that students agree that they will employ research approach in their profession (3.99), they have skills to write and will conduct research (3.70), they will apply theories of research in writing their thesis (3.90), incline to study details of research and will apply it (3.91), they will conduct research (3.85). 
On the negative behavioural component, as a whole, students' behavioural intention to conduct research is 2.11 which means disagree. Taking them singly, students deny or disagree that research is difficult and they cannot make it (2.21), that they do not have skills and have no plan to do it (2.06), that they find it hard to understand and cannot make it (2.17), that even they are promised to be promoted for conducting research, they will not do it (2.12).

4. Is there a relationship between cognitive and affective attitudes toward research subject and behavioural intention of students to conduct research?

Table 4. Relationship between Cognitive and affective attitudes toward research subject, and behavioural intention of students to conduct research

\begin{tabular}{|l|l|l|l|}
\hline \multicolumn{2}{|c|}{} & \multicolumn{2}{l|}{ Behavioural Intention } \\
\hline \multirow{4}{*}{ Positive Cognition } & Positive Intention & Negative Intention \\
\hline & Pearson Correlation & $.455^{* *}$ & $-.245^{* *}$ \\
\cline { 2 - 5 } & Sig. (2-tailed) & .000 & .006 \\
\cline { 2 - 5 } & $\mathrm{N}$ & 122 & 122 \\
\hline \multirow{4}{*}{ Negative Cognition } & Pearson Correlation & $-.350^{* *}$ & $.503^{* *}$ \\
\cline { 2 - 5 } & Sig. (2-tailed) & .000 & .000 \\
\cline { 2 - 5 } & $\mathrm{N}$ & 122 & 122 \\
\hline \multirow{4}{*}{ Disaffection } & Pearson Correlation & $-.293^{* *}$ & $.386^{* *}$ \\
\cline { 2 - 5 } & Sig. (2-tailed) & .001 & .000 \\
\cline { 2 - 5 } & $\mathrm{N}$ & 122 & 122 \\
\hline & Pearson Correlation & $.517^{* *}$ & $-.180^{*}$ \\
\cline { 2 - 5 } & Sig. (2-tailed) & .000 & .048 \\
\cline { 2 - 4 } & $\mathrm{N}$ & 122 & 122 \\
\hline
\end{tabular}

**. Correlation is significant at the 0.01 level (2-tailed).

*. Correlation is significant at the 0.05 level (2-tailed).

Looking into its correlation between students' positive and negative cognition and their behavioural intention to conduct research shows that both positive and negative cognition correlates significantly at 0.01 level (2-tailed). It means that both affects their intention to conduct research in the future. It is also the same with the positive affection and negative affection, the Pearson $r$ correlation reveals that both affection and disaffection toward research correlates significantly at 0.01 level (2-tailed) and 0.05 level (2-tailed) which means that both affects their behavioural intention to conduct research.

\section{CONCLUSION}

Based on the findings, the study concludes that students' positive cognition toward research is high or agree and their negative cognition is low or disagree. In terms of their affection toward research, it is found that students' affection toward research is still considered high or agree and their disaffection toward research is moderate or somewhat agree. While in terms of behavioural intention, the data shows that students' behavioural intention to conduct research is high or agree and their negative intention to conduct research is low or disagree. Finally, the hypothesis of the study, that there is a relationship between students' cognitive and affective attitude toward research and their intention to conduct research is accepted because both cognitive and affective attitude of students toward research and their intention to conduct research are correlated significantly. Their cognitive and affective attitude toward research affects their intention to conduct research.

\section{REFERENCES}

1. Abun, D. (2017). Environmental Attitude and Environmental Behavior of Catholic Colleges' Employees in Region I, Philippines. Texila International Journal of Academic Research, Vol. 4, Issue 1, June, 2017. 
2. Ajzen, I., \& Fishebin, M. (1980). Understanding attitude and predicting social behavior. Englewood-Cliffs, NJ: Prentice-Hall.

3. Ajzen, I. (1993). New Directions in Attitude Measurement. New York: Walter de Gruyter.

4. Ajzen, I., \& Fishbein, M. (2000). Attitudes and the Attitude-Behavior relation: Reasoned and Automatic Processes. In W. Stroebe \& M.Hewstone (Eds.). European Review of Social Psychology, Vol. 11, pp. 133. Chichester, UK: Wiley.

5. Ajzen, I., \& Fishbein, M. (1977). Attitude - Behavior Relations: A Theoretical Analysis and review of Empirical Research. Psychological Bulletin, 84, 888-918.

6. Ajzen, I. (1985). From Intention to Action: A Theory of Planned Behavior. In Kuhl, J., Beckmann, J., (Eds). Action Control: From Cognition to Behavior. Heidelberg: Springer.

7. Ajzen, I. (1987). Attitudes, Trait and Action: Dispositional Prediction of behavior in Personality and Social Psychology. In Berkowitz, L. (Ed.). Advances in Experiential Social Psychology, Vol. 20, pp. 1-63. New York: Academic Press.

8. Ajzen, I., \& Fishbein, M. (2015). The Influence of Attitude on Behavior. University of Pennsylvania: Annenberg School for Communication.

9. Al Furaikh, S.S., Al Omairi, B.E., \& Ganapathy, Th. (2017). A cross-sectional survey on nursing students' attitude towards research. Journal of Health Specialties, Vol. 5, issue, 4, pp. 185-191.

10. AlGhamdi, Kh.M., A.Moussa, N.A., AlEssa, D.S., Al Othimeen, N. \& Al-Saud, A.S. (2014). Perceptions, attitudes and practices toward research among senior medical students. Saudi Pharmaceutical Journal, Vol. 22, Issue, 2, pp. 113-117.

11. Allport, G.W. (1935). Attitudes. In C. Murchison (Ed). Handbook of Social Psychology. Worcester, MA: Clark University Press.

12. Allport, G.W. (1968). The Historical background of Modern Social Psychology. In G. Lindzay and E. Aronson (Eds.). Handbook of Social Psychology. Reading, MA: Addison-Wesley.

13. Allport, G.W. (1954). The Historical Background of Modern Social Psychology. In Lindzay, G. (Ed.). Handbook of Social Psychology, Vol. 1, pp. 3-56. Cambridge, MA: Addison-Wesley.

14. Amstrong, W. R. (1996). The Relationship between Culture and Perception of Ethical Problems in International Marketing, Journal of Business Ethics, Volume: 15, Issue: 11, Pages: 1199-1208.

15. Ariola, M.M. (2006). Principles and Methods of Research. Manila: National Bookstore

16. Banaji, M.R. \& Heiphetz, L. (2010). Attitudes. In S.T. Fiske, D.T. Gilbert \& G. Lindzey (Eds).

17. Handbook of Social Psychology (5th ed, Vol. 1, pp. 353-393. Hoboken, NJ: John Wiley \& Sons.

18. Bandura, A.; Adams, N. E.; Hardy, A. B.; Howells, G. N. (1980). "Tests of the generality of self-efficacy theory". Cognitive Therapy and Research. 4 (1): 39-66. Doi: 10.1007/bf01173354.

19. Basudan, A., Nazish, M., Aisha, Q., Lamia, A., Malk, A., \& Alburaidi Yara, A. (2019). Attitudes and Barriers toward Conducting Research among Dentists in National Guard Health Affairs, Riyadh. International Journal of Dentistry and Oral Health, Vol. 5, Issue, 1, 2019.

20. Belgrave, K.L., \&Jules, J.E., (2015). Students' Attitudes towards Research: Applying Best Practice Principles through a Student-Centered Approach. Unpublished Thesis. The University of the West Indies, Cave Hill Campus.

21. Bem, D.J. (1970). Beliefs, Attitudes and Human Affairs. Belmont, CA: Brooks/Cole.

22. Bibi, F., IqbalH.M., \& Majid, N., (2012). Attitude of Prospective Teachers toward Research: Implications for teachers in Pakistan. Journal of Contemporary Educational Research Journal, Vol. 1, pp.8-14.

23. Brown, A. (1995). Organizational Culture. London: Pitman Publishing.

24. Cherry, K. (2019). What exactly is self-Esteem? Verywellmind. Retrieved from https://www.verywellmind.com/what-is-self-esteem-2795868.

25. Corey, S. M. (1937). Professed attitudes and actual behaviour. Journal of Educational Psychology, 28(4), 271-280. http://dx.doi.org/10.1037/h0056871

26. Dean, L. (1958). Interaction, Reported and Observed: The Case of One Local Union. Human Organization, Vol.17, Issue 3, pp. 36-44, 1958.

27. DeFleur, M.L. \& Westie, F.R. (1958). Verbal Attitude and Overt Acts: An Experiment on the Salience of Attitude. American Sociological Review 23(6):667.

28. Deutscher, I. (1968). Looking Backward: Case Study on the Progress of methodology in sociological research. American Sociologist, Vol. 4, 35-41.

29. Donald, M. (2002). A Mind So Rare: The Evolution of Human Consciousness. New York: W.W. Norton \& Company, Inc.

30. Edwards, A.L. (1957). Technique of Attitude Scale Construction. New York: Appleton-Century-Crofts.

31. Faustino E. Oguan, F.E., Bernal, M.M., \& Pinca, M.Ch.D. (2014). Attitude and Anxiety towards Research, Its Influence on the Students' Achievement in the Course. Asian Journal of Management Sciences \& Education Vol. 3(4) October 2014. 
32. Fishbein, M., \& Ajzen, I. (1975). Beliefs, Attitude, Intention and behavior: An Introduction to theory and research. Reading, MA: Addison-Wesley.

33. Fitzsimmons, J.R., Douglas, E.J. (2005), "Entrepreneurial Attitudes and Entrepreneurial Intentions: A Cross-Cultural Study of Potential Entrepreneurs in India, China, Thailand And Australia", BabsonKauffman Entrepreneurial Research Conference, Wellesley, MA. June 2005.

34. Freeman, L. C., \& Ataoev, T. (1960). Invalidity of indirect and direct measures of attitude toward cheating. Journal of Personality, 28, 443-447.

35. Godin, B. (2003), Measuring Science: Is There Basic Research without Statistics, Social Science Information, 42 (1): 57-90.

36. Groessler, A. (2017). Teaching Research Method. Unpublished Research Paper: The University of Queensland.

37. Hilgard, E.R. (1980). The trilogy of Mind: Cognition, affection, and conation. Journal of the History of the Behavioral Sciences, 16, pp. 107-117.

38. Hofmeister, N. (2007). Attitudes of Nurses toward Research. Unpublished Masters Theses: Grand Valley State University.

39. Kakupa,P. \& Xue, H. (2019). Students' Attitudes towards Research: A Study of Graduate Education Students at a Chinese Normal University. Educational Process International Journal, Vol. 8, issue, 2, pp. 97-110.

40. Cherry, K. (2019). Attitudes and Human Behavior in Psychology. Very Well Mind. Retrieved from https://www.verywellmind.com/attitudes-how-they-form-change-shape-behavior-2795897.

41. Kumari, R., Langer, Bh., Singh, P., Kumar Gupta, R.K., Sharma, P. \& Gupta, R. (2018). Exploring attitude toward research and plagiarism among faculty members and senior residents in a medical school of North India: A cross-sectional study. International Journal of Medical Science and Public Health, Vol. 7, Issue 4.

42. Lane, J., \& Flagg, J.L. (2010), Translating Three States of Knowledge: Discovery, Invention and Innovation, $\quad$ Implementation Science, 5 (9). http://www.implementationscience.com/content/5/1/9.

43. Lawrence, P. \& Nohria, N. (2002). Driven: How Human Nature Shape Our Choices. New York: JosseyBass.

44. Lowler, M.S. (2006). William James's psychological pragmatism: habit, belief and purposive human behaviour. Cambridge Journal of Economics, Vol. 30, No. 3 (May 2006), pp. 321-345.

45. Memarpour, M., Fard, A. P., \& Roghieh Ghasemi, R. (2015). Evaluation of attitude to, knowledge of and barriers toward research among medical science students. Asia Pacific Family Medicine2015, Vol. 14, Issue 1., https://doi.org/10.1186/s12930-015-0019-2.

46. Monir, N., \& Bolderston, A. (2009). Perceptions and Attitudes toward Conducting Research: A Nuclear Medicine Student Perspective. Journal of Medical Imaging and Radiation Sciences, Vol. 40, Issue, 4, pp. 183-189.

47. Nohria, N., Sandelands, L., \& Lawrence, P.R. (2006). Driven: Human Nature Shapes Our Choices. Administrative Science Quarterly. Vol. 48, Issue 3.

48. Norberg, P. A.; Horne, D. R.; Horne, D. A. (2007). "The privacy paradox: Personal information disclosure intentions versus behaviors". Journal of Consumer Affairs. 41 (1): 100-126. Doi: 10.1111/j.17456606.2006.0007.

49. Papanastasiou, E.C. (2014). Factor Structure of the "Attitudes toward Research" Scale. Unpublished Research Paper: University of Nicosia. Retrieved from https://www.researchgate.net/publication/236028558_Factor_structure_of the 'Attitudes_Toward Resea rch'scale.

50. Reddy, Ch. (2019). Why Research is Important for Students, Humans and Education. Retrieved from https://content.wisestep.com/research-important-students-humans-education/ Rezaei, M., \& Miandashti, N.Z. (2013). Thd Relationship between Research Self-Efficacy, Research Anxiety and Attitude toward Research: A Study of Agricultural Graduate Students. Journal of Educational and Instructional Studies in the World, Vol. 3, Issue, 4. Ridley M. (2011). Nature Via Nurture: Genes, Experience and What Makes Us Human. New York: Harper Perennial.

51. Rosenberg, M.J. \& Hovland, C.I. (1960). Cognitive, Affective and Behavioral Components of Attitudes. In Hovland, C.I. \& Rosenberg, M.J. (Eds). Attitude Organization and Change, pp. 1-14. New haven, CT: Yale University Press.

52. Seher, U., Remziye, S., Kizilcik, O.Z. \& İlker, A. (2018). Attitude of Nursing Students toward Scientific Research A Cross-Sectional Study in Turkey. Journal of Nursing Research, Vol. 26, issue, 5, pp. 356-361.

53. Shaukat, S., Siddiquah, A., Abiodullah, M., \& Akbar, R.A. (2014). Postgraduate Students' Attitudes towards Research. Bulletin of Education and Research June 2014, Vol. 36, No. 1 pp. 111-122. 
54. Sheppard, B.H.; Hartwick, J.; Warshaw, P.R. (1988). "The theory of reasoned action: A meta-analysis of past research with recommendations for modifications and future research". Journal of Consumer Research. 15 (3): 325-343. Doi: 10.1086/20917.

55. Siamian, H., Mahmoudi,R., Habibi,F., Latifi,M., \& Zare-Gavgani, V. (2015). Students' Attitudes towards Research at Mazandaran University of Medical Sciences in 2015. Journal of the Academy of Medical Sciences of Bosnia and Herzegovina. Vol. 28, Issue, 6.

56. Soe, H.H.K., Than, N.N., Htay Lwin, H., Htay,M.N.N.N., Phyu,Kh.L. \& Abas, A.L. (2018). Knowledge, attitudes, and barriers toward research: The perspectives of undergraduate medical and dental students. Journal of Education and Health Promotion. Vol. 7, 2018. doi: 10.4103/jehp.jehp_61_17.

57. Swenson I, Kleinbaum, A. (1984). Attitudes toward research among undergraduate nursing students. The Journal of Nursing Education, Vol. 23, issue, 9, pp.380-386

58. Swindoll, C. R. (2012). Quotable quotes. Retrieved from http://www.goodreads.com/ quotes/267482-thelonger-i-live-the-more-i-realize-theimpact.

59. Thomas, W.I., \& Znaniecki, F. (1918). The Polish Peasant in Europe and America (vol. 1). Boston: Bedger.

60. Watson, J.B. (1925). Behaviorism. New York: Norton.

61. Wicker, A.W. (1969). Attitudes versus Actions: The relationship of verbal and overt behavioral responses to attitude objects. Journal of Social Issues, 25, 41-78.

62. Wicker, A. W., \& Pomazal, R. J. (1971). The relationship between attitudes and behavior as a function of specificity of attitude object and presence of a significant person during assessment conditions. Representative Research in Social Psychology, 2(2),

63. 26-31. Zarah, L. (2019). 7 Reasons why Research is Important. Retrieved from https://owlcation.com/academia/Why-Research-is-Important-Within-and-Beyond-the-Academe. 